\title{
In vitro Studies on Different Isolates of Fusarium oxysporum f sp. cubense Causing Panama Wilt of Banana in Lower Gangetic Plain
}

\author{
Debashis Rana $^{1 *}$, Sahar Murmu ${ }^{2}$ and Dilip Kumar Misra ${ }^{3}$ \\ ${ }^{1}$ Department of Plant Pathology, Bidhan Chandra Krishi Viswavidyalaya, Mohanpur, \\ Nadia-741252, West Bengal, India \\ ${ }^{2}$ Survey Selection and Mass Production of Nodule Bacteria, Directorate of Research, \\ Bidhan Chandra Krishi Viswavidyalaya, Mohanpur, Nadia-741252, West Bengal, India \\ ${ }^{3}$ AICRP on Fruits, Directorate of Research, Bidhan Chandra Krishi Viswavidyalaya, \\ Kalyani, Nadia741235, West Bengal, India \\ *Corresponding author
}

A B S T R A C T

\begin{tabular}{|c|}
\hline Keywords \\
\hline $\begin{array}{l}\text { Banana, Biomass, } \\
\text { Conidia, Disease, } \\
\text { Fusarium } \\
\text { oxysporum f.sp } \\
\text { cubense, Isolates, } \\
\text { Sporulation. }\end{array}$ \\
\hline Article Info \\
\hline $\begin{array}{l}\text { Accepted: } \\
10 \text { October } 2017 \\
\text { Available Online: } \\
10 \text { December } 2017\end{array}$ \\
\hline
\end{tabular}

Banana is one of the important fruit crop in tropical and subtropical countries suffering from numerous diseases. The panama wilt caused by Fusarium oxysporum f.sp cubense is the most destructive disease of banana. The pathogen has different races with different crop yield losses. Therefore we have studied on different isolates of the pathogen about the morphology and growth behaviour in different media for further studies on in vitro as well as in vivo management of this disease. After extensive survey in different districts, a total of 14 isolated of the pathogen were collected from different varieties. These different isolates were allowed to grow in different media. Among them potatoes dextrose agar was recorded as the best artificial media for growth and sporulation of all the isolates. Great variation was recorded both in growth (biomass production) and sporulation of the isolates. Production of conidia and ratio of macro and micro conidia are also significantly differed among the 14 isolates of $F o c$. So from these studies it may be reached to the point that there was probable variability in aggressiveness of different isolates of the pathogen as well as in the development of disease symptom on different varieties in different locations.

\section{Introduction}

Banana (Musa spp.) is an important cash and food crop in the tropical and subtropical countries in the world. Fusarium wilt, popularly known as Panama wilt or Panama disease of banana is caused by the fungus Fusarium oxysporum f. sp. cubense (Foc). In commercial cultivation Fusarium wilt is one of the most destructive diseases of banana (Ploetz and Pegg, 2000). As Indu-Burma region is considered to be the centre of the crop, thus it is suspected that the pathogen probably originated in Southeast Asia (Ploetz and Pegg, 1997; Ploetz, 2007; Stover, 1962 ;), currently, the disease is found in virtually all areas where banana is grown. In India, the disease is present in almost all the banana growing states and causes severe yield losses in most of the commercial cultivars grown. Although the disease was recorded only in the susceptible host with race 1 and race 2 of Foc. Great variation among the isolates of Foc has been established but the information about the 
characteristics of isolates of different locality in India is meager. To assess the variation among the isolates having spatial differences the present investigation was done to evaluate cultural characteristics of Fusarium oxysporum f sp cubense isolates including their sporulating behaviour and nutritional requirement among the tested isolates in artificial culture.

\section{Materials and Methods}

An extensive survey work has been done to study the distribution status of wilt disease in West Bengal. Finer roots and rhizome from infected plants were collected from different districts of West Bengal for isolation of rhizome infecting fungus of different varieties of banana (Plate 1). Affected rhizome were cleaned, cut in to small pieces $(2-3 \mathrm{~mm}$ diameter cube) and were surface sterilized with freshly prepared $0.1 \% \mathrm{HgCl}_{2}$ solution.

After serial washing with sterile water \& the rhizome pieces were aseptically transferred to pre-sterilized Petriplates with lined with blotting paper. The plates were incubated at $28 \pm 2{ }^{0} \mathrm{C}$. Within 3-5 days a white cottony growth appears from the surface of the rhizome pieces. The mycelial growth of the pathogen was transferred to PDA slant to isolate pure culture of the fungus for further use. After full growth of the fungus on the Petri plates the colony morphology of different fungal isolates were studied and recorded accordingly. Comparative study of both micro-conidia and micro-conidia of the isolates were also assessed by counting the number of spores in $1.0 \mathrm{ml}$ of suspension using the haemocytometer the total spore population was calculated. Size of spores was measured on the basis of micro and macroconidia with the help of microscope. Biomass productions of different Fusarium isolates were estimated by inoculating the fungi to the broth medium of PDA and BPA. From these the exact fungal biomass of different Fusarium isolates was calculated.

\section{Results and Discussion}

\section{Cultural characterization of Fusarium isolates grown in different media}

Three different media including natural and semi-synthetic media were used for this investigation are Oat-meal agar medium (OMA), potato dextrose agar medium (PDA) and banana pseudo-stem extract agar (BEA) media.

Morphological variations were recorded among the ten Foc isolates when grown in three different culture media (Table 1). In most cases isolates favours PDA medium for their growth and development in in-vitro (Plate 2). Most of the isolates produce light to dark, pink or violet pigments in the culture medium. Isolates were also recorded as highly variable in respect of their nature of growth and development.

Similar type of observation was also reported by Groenewald et al., (2006) where the colony morphology of different Foc isolates and was divided into three morphological types, namely: sporodochial, cottony and slimy pionnotal. According to him the sporodochial type was the most dominant morphological type containing 15 isolates, while six isolates could be described as cottony and five as slimy pionnotal.

Determination of radial growth of Fusarium isolates in different solid media

The pathogen was grown in different commonly used media. The aggressive fungus grows well in all three media (PDA, OMA, BEA) tested for their radial growth. It covers the whole Petriplates $(90 \mathrm{~mm})$ within a period of 9 days only. All the isolates can utilize any 
form of carbohydrate source and other nutrients from the media and readily sporulate sufficiently. The average growth of 14 isolates of $F o c$ in PDA, OMA and BEA are $37.95 \mathrm{~mm}, 23.98 \mathrm{~mm}$ and $31.40 \mathrm{~mm}$ respectively at $72 \mathrm{hrs}$ after inoculation. Maximum radial growth was obtained from Foc-9 and Foc-14 (45.00 mm) in PDA medium at $72 \mathrm{hrs}$ after inoculation. In OMA medium the highest growth was recorded in Foc-6 $(30.66 \mathrm{~mm})$ while, in BEA medium the maximum growth was $43.1 \mathrm{~mm}$ which is statistically at per. The Foc-11only shows poor growth $(17.00 \mathrm{~mm})$ in OMA medium as compare to other media

At 5 days after inoculation, the maximum growth was obtained in Foc-7 (69 mm) using
BPA medium. The average growth of all the isolates in 3 different media, PDA, CDA and BPA (Banana pseudostem agar) were recorded as $59.51 \mathrm{~mm}, 39.52 \mathrm{~mm}$ and 57.16 $\mathrm{mm}$ respectively (Table 2 and Fig. 1).

Groenewald et al., (2006) studied that differences in growth rate among isolates of Foc subtropical race 4 (VCG 0120) were substantial. An average colony diameter of more than $50 \mathrm{~mm}$ was achieved by five isolates (CAV 001, CAV 015, CAV 041, CAV 086, and CAV 129) and these isolates had a significantly faster growth rate than the other isolates, supported by $95 \%$ confidence intervals. All other isolates had colony diameters between 30 and $50 \mathrm{~mm}$. CAV 145 had the slowest growth rate of all isolates.

Plate.1 Panama wilt symptoms of banana: (A) Wilting of the plant, (B) Discolouration of vascular bundle in peduncle (C) Splitting of pseudostem at initial stage, (D) Petiole breaking and (E) Isolation of pathogen
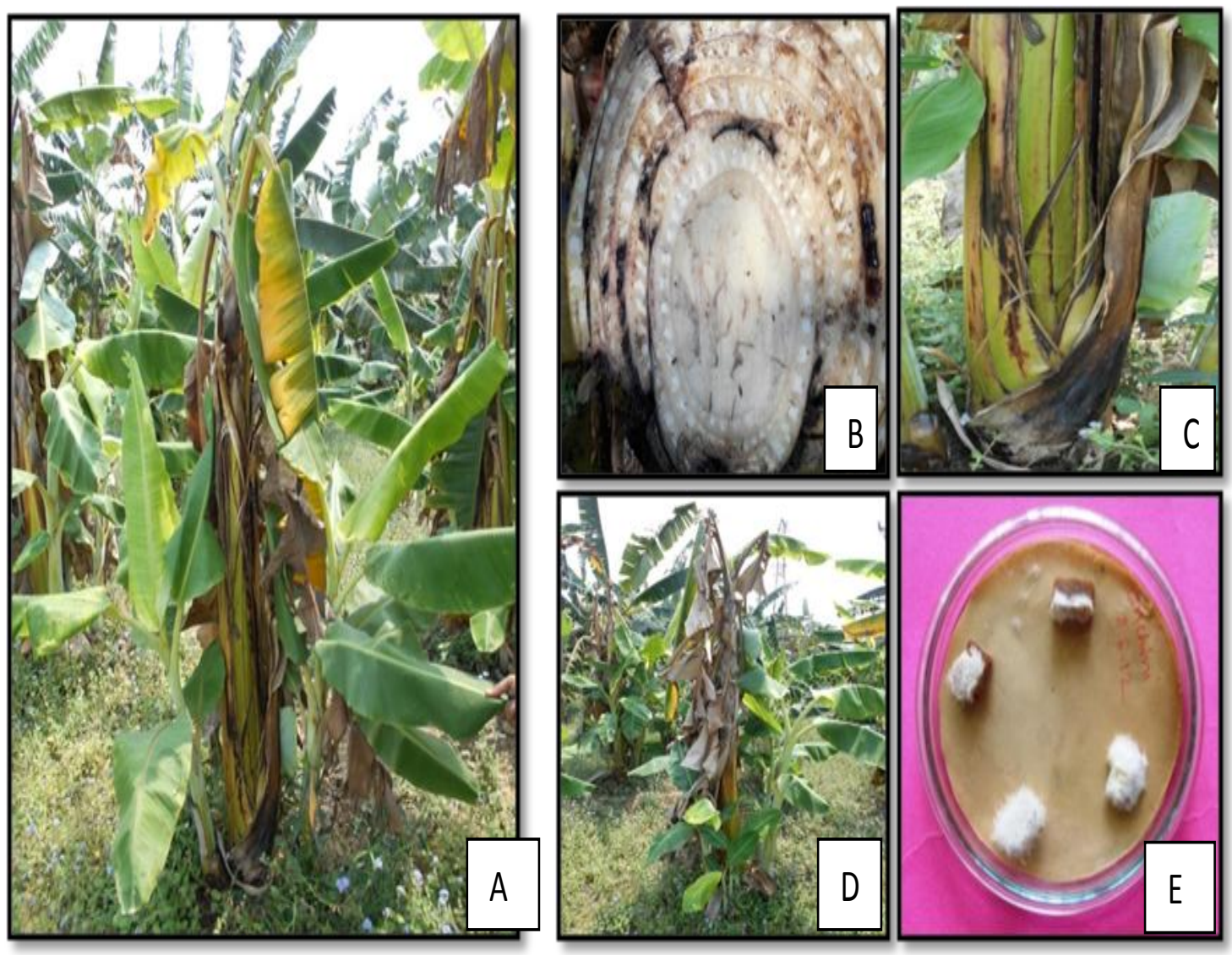
Plate.2 Fusarium isolates growing in PDA medium
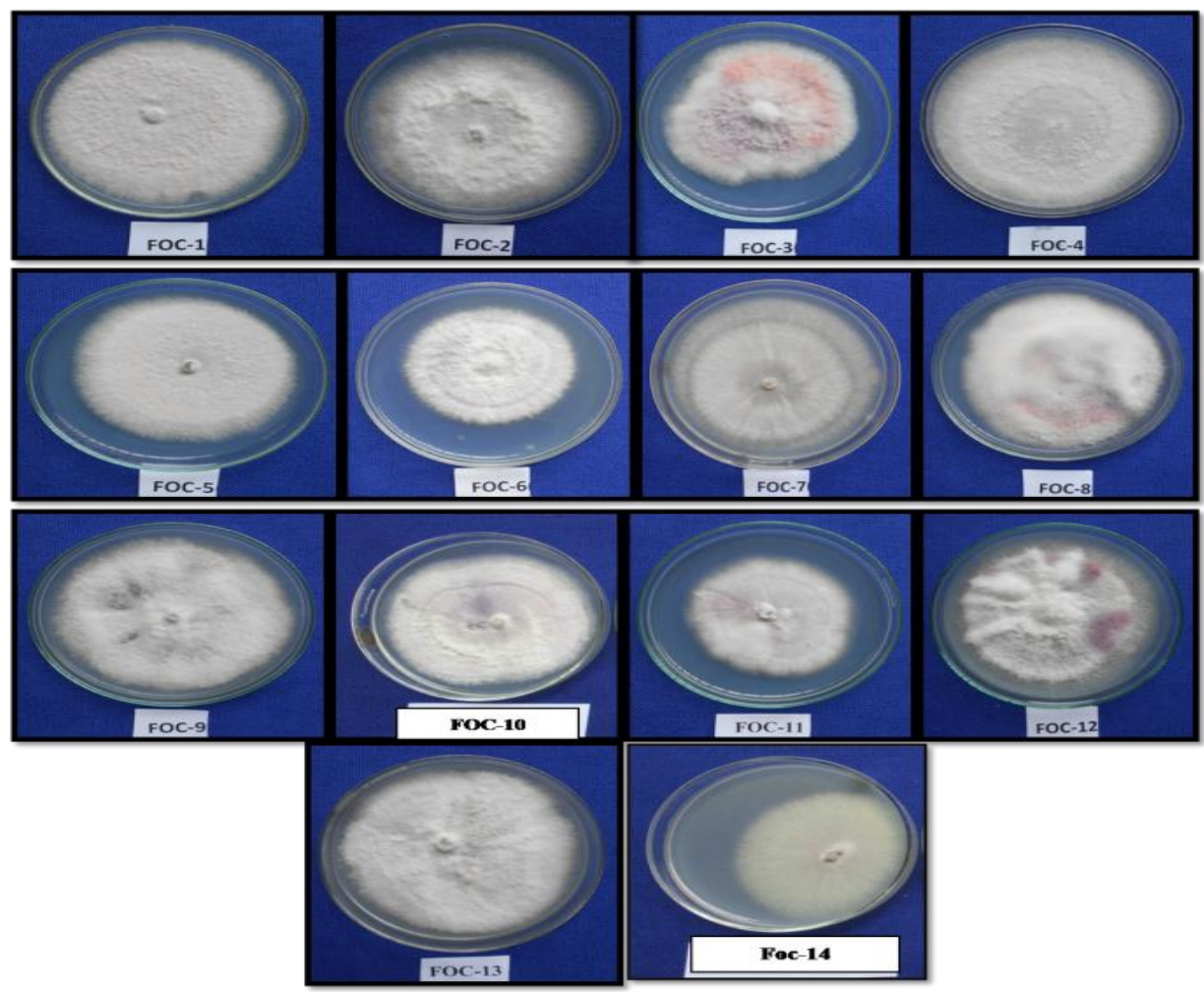

Plate.3 Microscopic photograph of Micro condia and Macro condia (40x) of different isolates of Fusarium oxysporum f.sp cubense isolates
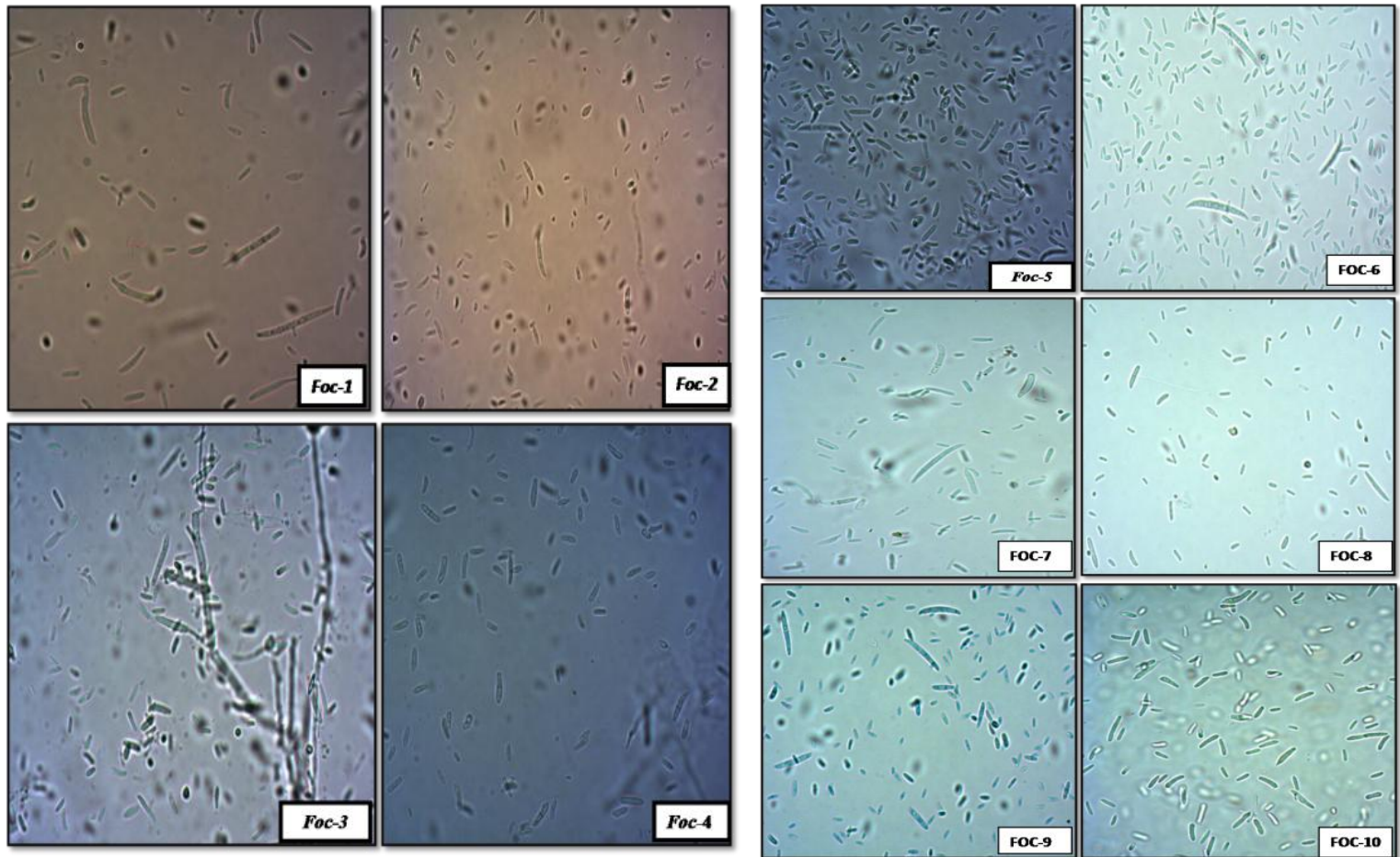
Fig.1 Radial growth variation Fusarium isolates in PDA, OMA, BEA media at $8^{\text {th }}$ day after incubation

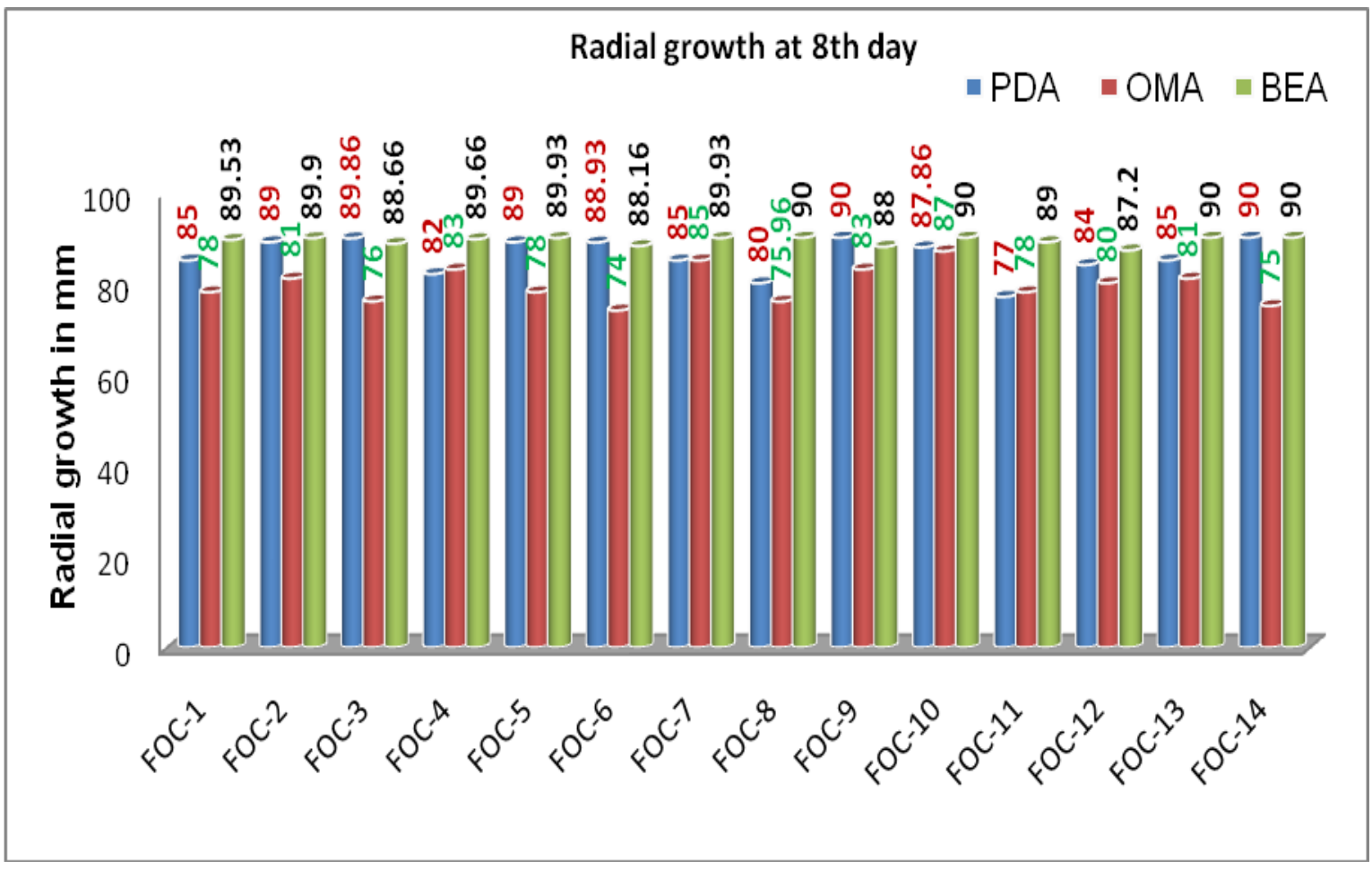

Fig.2 Biomass production of Fusarium isolates in different media

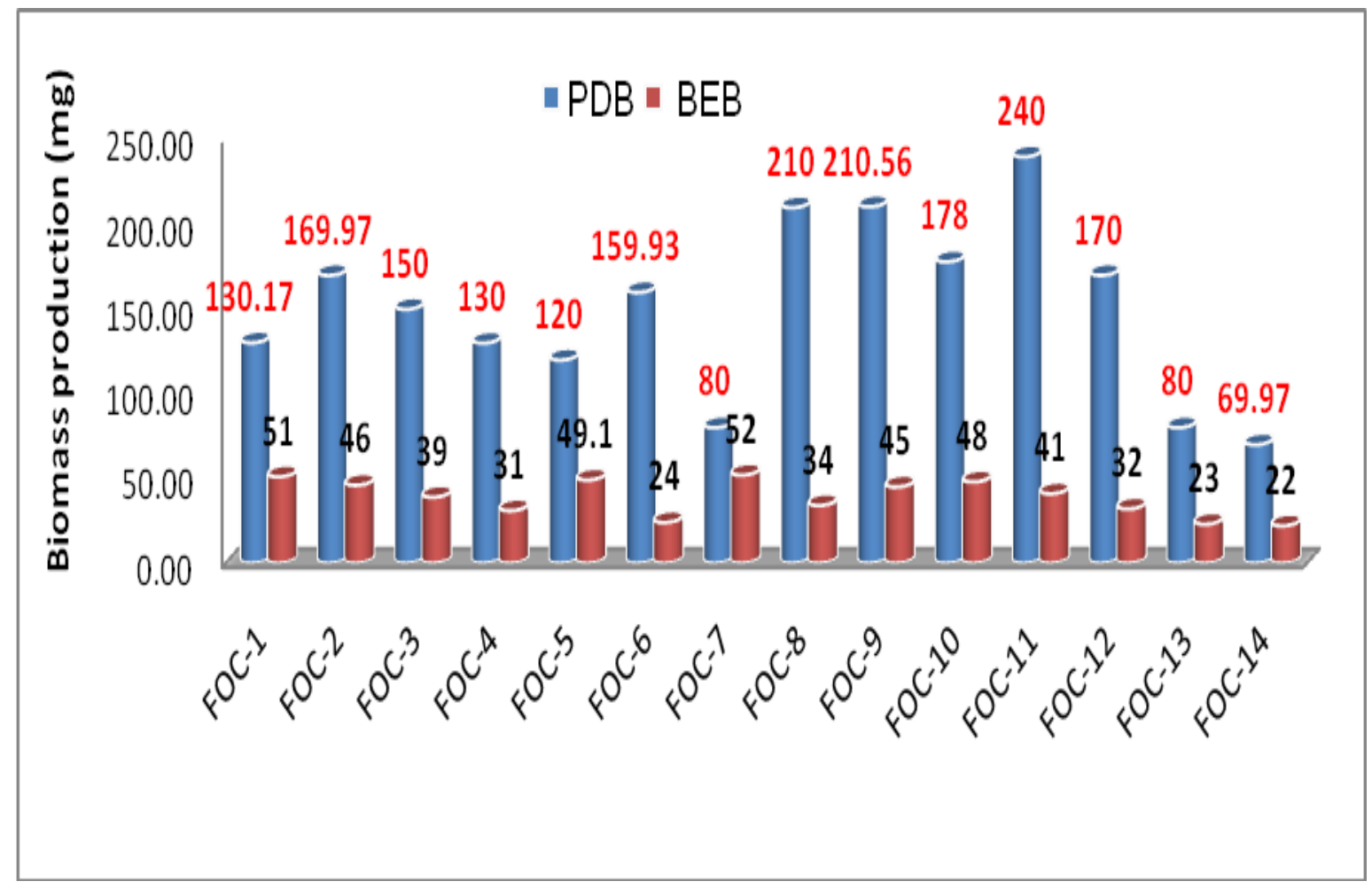


Table.1 Growth behavior of $F O C$ isolates on different media

\begin{tabular}{|c|c|c|c|}
\hline Isolate & PDA & OMA & BEA \\
\hline FOC-1 & $\begin{array}{l}\text { Very vigorous, very floppy, } \\
\text { huge mass, violet colour } \\
\text { pigmentation }\end{array}$ & $\begin{array}{l}\text { Dispersal mycelia growth } \\
\text { with pink colouration and } \\
\text { clear margin. }\end{array}$ & $\begin{array}{l}\text { Very thin growth, } \\
\text { extremely less } \\
\text { biomass production }\end{array}$ \\
\hline$F O C-2$ & $\begin{array}{l}\text { Thin but vigorous growth, } \\
\text { light pink pigmentation }\end{array}$ & $\begin{array}{l}\text { Profuse mycelium with } \\
\text { clear white centre and pink } \\
\text { colouration. }\end{array}$ & $\begin{array}{l}\text { Thin and sparse } \\
\text { growth on the } \\
\text { surface }\end{array}$ \\
\hline FOC-3 & $\begin{array}{l}\text { Huge mass, extremely } \\
\text { fluppy, very light pinkish } \\
\text { pigmentation }\end{array}$ & $\begin{array}{l}\text { Comparatively slow } \\
\text { growth with clear white } \\
\text { margin with floppy } \\
\text { mycelium and central } \\
\text { pigmented area. }\end{array}$ & $\begin{array}{l}\text { Dispersed growth, } \\
\text { no pigmentation }\end{array}$ \\
\hline$F O C-4$ & Whitish mat like, little mass & $\begin{array}{l}\text { Vigorous growth and } \\
\text { highly pigmented }\end{array}$ & Thin mycelia growth \\
\hline FOC -5 & $\begin{array}{l}\text { Thin growth, less mass, } \\
\text { violet pigmentation }\end{array}$ & $\begin{array}{l}\text { Profuse mycelia growth, } \\
\text { evenly arranged with light } \\
\text { pigmentation. }\end{array}$ & $\begin{array}{l}\text { Dispersed growth } \\
\text { with isolated } \\
\text { mycelium }\end{array}$ \\
\hline FOC-6 & No fluppyness, thin growth & $\begin{array}{l}\text { Slow growth, white margin } \\
\text { with floppy mycelium. }\end{array}$ & $\begin{array}{l}\text { Thin mycelia } \\
\text { growth, no } \\
\text { pigmentation }\end{array}$ \\
\hline FOC-7 & Thin but vigorous growth, & $\begin{array}{l}\text { Thick, evenly grown } \\
\text { colourless mycelium, no } \\
\text { pigmentation }\end{array}$ & $\begin{array}{l}\text { Light colourless thin } \\
\text { growth }\end{array}$ \\
\hline FOC-8 & $\begin{array}{l}\text { Profuse mycelia, vigorously } \\
\text { growth, very light pinkish } \\
\text { pigmentation }\end{array}$ & $\begin{array}{l}\text { Isolated floppy growth and } \\
\text { little pink pigmentation }\end{array}$ & $\begin{array}{l}\text { Vigorous or fast } \\
\text { growth but no } \\
\text { compactness. }\end{array}$ \\
\hline FOC-9 & $\begin{array}{l}\text { Very light pigmentation, } \\
\text { fast growth. }\end{array}$ & $\begin{array}{l}\text { Radial mycelium growth } \\
\text { with light pigmentation }\end{array}$ & $\begin{array}{l}\text { Light growth, no } \\
\text { pigmentation }\end{array}$ \\
\hline $\begin{array}{l}\text { FOC }- \\
10\end{array}$ & $\begin{array}{l}\text { Huge mass, extremely } \\
\text { fluppy, extreme violet } \\
\text { pigmentation }\end{array}$ & $\begin{array}{l}\text { Thick, pink colouration } \\
\text { and clear margin. }\end{array}$ & $\begin{array}{l}\text { Comparatively fast } \\
\text { growth but no } \\
\text { pigmentation }\end{array}$ \\
\hline $\begin{array}{l}\text { FOC } \\
11\end{array}$ & $\begin{array}{l}\text { Pure white, compact } \\
\text { growth, very light creamy } \\
\text { white pigmentation }\end{array}$ & $\begin{array}{l}\text { Dispersal mycelium, light } \\
\text { growth, no pigmentation. }\end{array}$ & $\begin{array}{l}\text { Fast mycelia growth } \\
\text { no pigmentation }\end{array}$ \\
\hline $\begin{array}{l}\text { FOC }- \\
12\end{array}$ & $\begin{array}{l}\text { Comparatively light growth, } \\
\text { thin layers, pink } \\
\text { pigmentation }\end{array}$ & $\begin{array}{l}\text { Vigorous growth with dark } \\
\text { pigmentation }\end{array}$ & $\begin{array}{l}\text { Light dispersed } \\
\text { growth, no } \\
\text { pigmentation }\end{array}$ \\
\hline $\begin{array}{l}\text { FOC }- \\
13\end{array}$ & $\begin{array}{l}\text { thin layered mycelia with } \\
\text { light pigmentation }\end{array}$ & $\begin{array}{l}\text { Profuse growth with light } \\
\text { pigmentation }\end{array}$ & $\begin{array}{l}\text { Vigorous or fast } \\
\text { growth but no } \\
\text { compactness }\end{array}$ \\
\hline $\begin{array}{l}\text { FOC- } \\
14\end{array}$ & $\begin{array}{l}\text { dispersal white mycelia } \\
\text { growth in the medium }\end{array}$ & $\begin{array}{l}\text { Thin,evenly grown } \\
\text { colourless mycelium, no }\end{array}$ & $\begin{array}{l}\text { Extreme little mass } \\
\text { with dispersed } \\
\text { growth }\end{array}$ \\
\hline
\end{tabular}


Table.2 Comparative growth behaviour of Foc isolates in different media at different days after incubation

\begin{tabular}{|c|c|c|c|c|c|c|c|c|c|c|c|c|}
\hline \multirow[t]{2}{*}{ Isolates } & \multicolumn{3}{|c|}{3 DAI } & \multicolumn{3}{|c|}{5 DAI } & \multicolumn{3}{|c|}{7 DAI } & \multicolumn{3}{|c|}{8 DAI } \\
\hline & PDA & OMA & BPA & PDA & OMA & BPA & PDA & OMA & BPA & PDA & OMA & BPA \\
\hline$F O C-1$ & 41 & 26 & 35 & 69 & 43 & 51 & 72 & 61 & 85 & 85 & 78 & 90 \\
\hline FOC-2 & 43 & 23 & 39 & 63 & 39 & 60 & 71 & 55 & 88 & 89 & 81 & 90 \\
\hline$F O C-3$ & 35 & 21 & 31.2 & 49 & 42 & 53 & 66 & 55 & 84 & 90 & 76 & 89.1 \\
\hline$F O C-4$ & 40 & 29 & 33 & 66 & 51 & 65 & 74 & 70 & 89.1 & 82 & 83 & 90 \\
\hline FOC-5 & 32 & 27 & 31 & 54 & 43 & 57 & 62 & 61 & 87 & 89 & 78 & 90 \\
\hline$F O C-6$ & 36 & 31 & 35 & 59 & 42 & 61 & 72 & 58 & 83 & 89 & 74 & 88 \\
\hline FOC-7 & 41 & 26 & 43 & 69 & 50 & 69 & 74 & 71 & 90 & 85 & 85 & 90 \\
\hline$F O C-8$ & 34 & 19 & 33 & 53 & 38 & 65 & 69 & 58 & 89 & 80 & 76 & 90 \\
\hline$F O C-9$ & 45 & 21 & 35.5 & 63 & 45 & 35 & 73 & 62 & 83 & 90 & 83 & 87.6 \\
\hline$F O C-10$ & 42 & 26 & 34 & 71 & 35 & 56 & 81 & 62 & 87 & 88 & 87 & 90 \\
\hline$F O C-11$ & 29 & 17 & 29 & 51 & 36 & 65 & 73 & 63 & 88 & 77 & 78 & 90 \\
\hline FOC-12 & 31 & 18 & 30 & 53 & 49 & 49 & 75 & 64 & 79 & 84 & 80 & 86.9 \\
\hline$F O C-13$ & 38 & 24 & 32 & 48 & 42 & 62 & 68 & 57 & 90 & 85 & 81 & 90 \\
\hline$F O C-14$ & 45 & 29 & 33 & 65 & 48 & 51 & 74 & 55 & 88 & 90 & 81 & 90 \\
\hline S.E(m) & 1.49 & 1.15 & 1.24 & 1.01 & 0.95 & 1.00 & 0.92 & 0.96 & 1.06 & 0.86 & 1.13 & 0.49 \\
\hline CD at $5 \%$ & 4.36 & 3.37 & 3.96 & 2.96 & 2.79 & 2.90 & 2.68 & 2.82 & 3.09 & 2.50 & 3.30 & 1.43 \\
\hline
\end{tabular}

Table.3 Studies on morphology and growth (bio-mass production) of

Foc isolates in liquid media

\begin{tabular}{|c|c|c|c|}
\hline \multirow{2}{*}{$\begin{array}{c}\text { Isolates } \\
\text { tested }\end{array}$} & \multirow[b]{2}{*}{ Cultural morphology of Foc isolates in PDA broth } & PDA & BEA \\
\hline & & $\begin{array}{l}\text { Dry weight of } \\
\text { biomass (mg) }\end{array}$ & $\begin{array}{c}\text { Dry wt. of } \\
\text { biomass (mg) }\end{array}$ \\
\hline Foc -1 & $\begin{array}{l}\text { Light purple colour, major pigmentation at the edge of the } \\
\text { culture }\end{array}$ & 130.50 & 51.00 \\
\hline Foc-2 & No pinkish or violet colour, only whitish growth. & 170.00 & 46.00 \\
\hline Foc -3 & Dark violet colour pigmentation & 150.00 & 39.00 \\
\hline Foc -4 & Only whitish growth, No pigmentation & 130.00 & 31.00 \\
\hline Foc -5 & Pinkish colour pigmentation & 120.00 & 49.00 \\
\hline Foc-6 & Very light pinkish colour pigmentation & 160.20 & 24.00 \\
\hline Foc -7 & No pinkish or violet colour, only whitish growth. & 80.00 & 52.00 \\
\hline Foc -8 & Very light pinkish pigmentation & 240.00 & 34.00 \\
\hline Foc-9 & Light violet colour pigmentation & 200.00 & 45.00 \\
\hline Foc -10 & Pinkish colour pigmentation & 178.00 & 48.00 \\
\hline Foc -11 & $\begin{array}{l}\text { Pure white, compact growth formed solid mycelia mat, very } \\
\text { light creamy white pigmentation }\end{array}$ & 240.00 & 41.00 \\
\hline Foc-12 & $\begin{array}{l}\text { Comparatively light mycelia growth, thin layers having } \\
\text { pink pigmentation }\end{array}$ & 190.00 & 32.00 \\
\hline Foc-13 & $\begin{array}{l}\text { Greyish white, thin layered mycelia with light violet pink } \\
\text { pigmentation }\end{array}$ & 80.00 & 23.00 \\
\hline Foc-14 & $\begin{array}{l}\text { Ashy white mycelial growth dispersed in the medium } \\
\text { having no pigmentation }\end{array}$ & 70.00 & 22.00 \\
\hline S.E(m) & & $\mathbf{5 . 3 3 4}$ & 1.239 \\
\hline CD at $5 \%$ & & 15.531 & 3.607 \\
\hline
\end{tabular}


Table.4 Spore population and spore size of different Foc isolates in PDA

\begin{tabular}{|c|c|c|c|c|}
\hline \multirow[t]{2}{*}{ Isolate } & \multicolumn{2}{|c|}{ Spore population (lakh/ml) } & \multicolumn{2}{|c|}{ Spore (conidia) size $(\mu)$} \\
\hline & Micro conidia & Macro conidia & Micro conidia & Macro conidia \\
\hline Foc-1 & 3.20 & 0.75 & $\begin{array}{c}6.6-11.28 \times 2.1-2.88 \\
(\mathbf{9 . 0 8} \times \mathbf{2 . 4})\end{array}$ & $\begin{array}{c}10.99-13.06 \times 2.58-4.74 \\
(\mathbf{1 2 . 3 0} \times \mathbf{3 . 7 3})\end{array}$ \\
\hline Foc-2 & 16.50 & 1.75 & $\begin{array}{c}5.41-10.19 \times 2.82-4.29 \\
(\mathbf{7 . 5 8} \times \mathbf{3 . 5 0})\end{array}$ & $\begin{array}{c}12.89-25.35 \times 2.58-6.66 \\
(\mathbf{2 3 . 8 2} \times \mathbf{4 . 6 2})\end{array}$ \\
\hline Foc -3 & 9.50 & 0.75 & $\begin{array}{c}10.25-14.46 \times 2.6-4.69 \\
(\mathbf{1 1 . 5 6} \times \mathbf{3 . 4 2})\end{array}$ & $\begin{array}{c}13.69-21.19 \times 2.58-3.65 \\
(\mathbf{1 7 . 4 4 - 3 . 1 1 )}\end{array}$ \\
\hline Foc -4 & 3.50 & 0.75 & $\begin{array}{c}5.65-7.18 \times 2.43-2.7 \\
(\mathbf{6 . 5 3} \times \mathbf{2 . 6 9 )}\end{array}$ & $\begin{array}{c}14.28-34.07 \times 3.75-5.33 \\
(\mathbf{2 1 . 1 2} \times \mathbf{4 . 2 6})\end{array}$ \\
\hline Foc -5 & 3.00 & 0.50 & $\begin{array}{c}5.3-7.3 \times 1.99-3.09 \\
(\mathbf{6 . 4} \times \mathbf{2 . 5 7})\end{array}$ & $\begin{array}{c}12.12-13.17 \times 3.06-4.3 \\
(\mathbf{1 3 . 1 2} \times \mathbf{3 . 6 3})\end{array}$ \\
\hline Foc-6 & 13.20 & 2.40 & $\begin{array}{c}4.94-6.41 \times 2.67-3.2 \\
(\mathbf{5 . 9 4} \times \mathbf{2 . 9 8 )}\end{array}$ & $\begin{array}{c}12.65-15.49 \times 3.0-4.37 \\
(\mathbf{1 2 . 4 6} \times \mathbf{3 . 7 4})\end{array}$ \\
\hline Foc -7 & 8.67 & 1.50 & $\begin{array}{c}4.1-7.04 \times 1.85-2.14 \\
(\mathbf{5 . 6} \times \mathbf{1 . 9 2 )}\end{array}$ & $\begin{array}{c}15.56-33.47 \times 2.98-3.68 \\
(\mathbf{2 2 . 9 9} \times \mathbf{3 . 1 7})\end{array}$ \\
\hline Foc -8 & 2.20 & 1.00 & $\begin{array}{c}7.53-16.96 \times 1.96-42 \\
(\mathbf{1 0 . 4 2 \times 2 . 5 1 )}\end{array}$ & $\begin{array}{c}22.47-29.4 \times 4.06-7.06 \\
(\mathbf{2 5} \times \mathbf{5 . 5 6})\end{array}$ \\
\hline Foc -9 & 6.20 & 1.50 & $\begin{array}{c}6.84-7.79 \times 2.67-3.38 \\
(\mathbf{7 . 3 6} \times \mathbf{2 . 7 8})\end{array}$ & $\begin{array}{c}17.41-29.38 \times 3.85-5.28 \\
(\mathbf{2 5 . 7 5} \times \mathbf{4 . 5 2})\end{array}$ \\
\hline Foc -10 & 17.25 & 4.25 & $\begin{array}{c}6.1-13.62 \times 1.93-3.88 \\
\quad(\mathbf{8 . 0 1} \times \mathbf{3 . 1 5})\end{array}$ & $\begin{array}{c}15.38-18.36 \times 3.66-3.88 \\
(\mathbf{1 6 . 8 7} \times \mathbf{3 . 7 7})\end{array}$ \\
\hline Foc-11 & 38.20 & 5.25 & $\begin{array}{c}6.45-12.54 \times 1.7-3.46 \\
(\mathbf{9 . 4 9} \times \mathbf{2 . 6 0})\end{array}$ & $\begin{array}{c}17.75-29.79 \times 2.56-3.10 \\
(\mathbf{2 3 . 3 7} \times \mathbf{2 . 8 3})\end{array}$ \\
\hline Foc -12 & 33.40 & 2.50 & $\begin{array}{c}5.17-10.84 \times 1.73-3.6 \\
(\mathbf{7 . 3 9} \times \mathbf{2 . 5 9 )}\end{array}$ & $\begin{array}{c}11.01-11.09 \times 2.6 \times 2.39 \\
(\mathbf{1 1 . 4 7 \times 2 . 4 9 )}\end{array}$ \\
\hline Foc -13 & 8.50 & 2.10 & $\begin{array}{c}4.82-6.71 \times 1.78-2.76 \\
(\mathbf{5 . 8 2} \times \mathbf{2 . 3 8})\end{array}$ & $\begin{array}{c}10.26-29.36 \times 1.74-4.08 \\
(\mathbf{1 5 . 4 3 - 3 . 0 3 )}\end{array}$ \\
\hline Foc-14 & 21.50 & 2.50 & $\begin{array}{c}4.85-6.12 \times 2.03-2.77 \\
(\mathbf{5 . 5 6 - 2 . 4 3 )}\end{array}$ & $\begin{array}{c}14.04-18.98 \times 3.14-4.04 \\
(\mathbf{1 6 . 3 5}-3.44)\end{array}$ \\
\hline
\end{tabular}

Determination of biomass production of Fusarium isolates in different liquid media

Total biomass production of different isolates of Foc was estimated in two different laboratory media as liquid culture. In general semi synthetic medium (PDB) is favoured by all the isolates as compared to natural medium -BLEB (Banana leaf extract broth). Variation among the Fusarium isolates was recorded during broth culture, both for their morphological as well as the colouration of mycelial mat. Different types of pigmentation like purple, violet, and pink colour were observed in the liquid culture. However the isolates Foc-2, Foc-4 Foc-7 Foc-14 have no pigmentation. Significant variation in biomass production was recorded among the isolates even in the most favoured medium (PDB) presented in Table 3 and Figure 2. Growth of Foc-11, Foc-8, Foc-9, Foc-12 and Foc 10 were highly significant as compare to other isolates. The maximum biomass production was obtained from Foc-11 and Foc-8 (240 $\mathrm{mg}$ ); on the other hand Foc-13 and Foc-14 have very low biomass production capacity 
(70 $\mathrm{mg}$ and $75.5 \mathrm{mg}$ respectively). Significant differences on biomass production were observed when the same isolates grown in different media. As for example biomass production of Foc-1 was $130.5 \mathrm{mg}$ in PDB while $51 \mathrm{mg}$ in BLEB. In another case Foc-14 having $22 \mathrm{mg}$ biomass in BLEB as compared to $70 \mathrm{mg}$ in PD broth.

In this investigation it can be concluded that medium containing host extract from pseudostem not supported the in vitro biomass production of the fungus. Out of the two media the semi synthetic one (PDB) showed the better result for biomass production of $F O C$ irrespective of all the isolates.

Schippers and Van Eck (1981) proposed that chlamydospore formation depends on the nutrient status of the inoculum, under field conditions, fungal inoculums may be subjected to much lower nutrient levels when compared to the 'well-fed' macroconidia produced on rich agar media. Once carbohydrates are released from decaying plant tissue or from roots, chlamydospore germination is stimulated.

\section{Estimation of spore population and measurement of spore size of different Fusarium isolates}

Sporulation studies of Foc isolates were done in the laboratory using media like PDA. Significant variations were recorded among the isolates both in respect of spore production and size of individual spore i.e. macro and micro conidia. Most of the isolates prefer PDA medium for their spore production in artificial culture $(25.0 \times 5.56 \mu)$ was measured in Foc-8 which is almost similar to macro conidia of Foc-9 $(25.75 \times 4.52 \mu)$. The minimum size of macro conidia average recorded was $(11.47 \times 2.49 \mu)$. The observation recorded about the spore population in different isolates (Table 4 and Plate 3).

Similarly size of spores that is both micro and macro conidia were also measured by Wardlaw, (1961) where the variation of 3 celled septate conidia ranges from 20-30 $\mu \mathrm{x}$ 4-4.5 $\mu$. In case of micro conidia the size varies from $5-8 \times 2.5 \mu$. The pathogen frequently produces chlamydospores in the artificial culture.

Above studies revealed that panama wilt of banana caused by the fungus Fusarium oxysporum f.sp. cubense is the most important disease causing severe damage to the crop. Different isolates of pathogen were associated with the formation of the disease. These isolates of the pathogen collected from different varieties exhibited potatoes dextrose agar (PDA) as the best artificial media for growth and sporulation from their growth characteristics in different media. Maximum radial growth was obtained from Foc-9 and Foc-14 $(45.00 \mathrm{~mm})$ in PDA medium at $72 \mathrm{hrs}$ after inoculation. In OMA medium the highest growth was recorded in Foc-6 (31.00 $\mathrm{mm}$ ) while in BPA medium the maximum growth was $43.00 \mathrm{~mm}$ recorded from Foc-7. Great variation was recorded both in growth (biomass production) and sporulation of these isolates. The maximum biomass production was obtained from Foc-11 and Foc-8 (240 mg) lowest from Foc-13 and Foc-14 (70 mg and $75.5 \mathrm{mg}$ ). Production of conidia and ratio of macro and micro conidia are also significantly differed among these 14 isolates of Foc.

\section{References}

Groenwald, S., van den Berg, N., Marasas, W.F.O. and Viljoen, A. (2006). The application of high-throughput AFLP's in assessing genetic diversity in Fusarium oxysporum f. sp. cubense. 
Mycol. Res. 110:297-305

Ploetz, R.C. and Pegg, K. (2000). Fusarium wilt. In: Diseases of Banana, Abaca and Enset. Jones, D.R. (Ed). CABI Publishing, Wallingford, UK. Pp. 143159.

Ploetz, R.C. and Pegg, K.G. (2000). Fusarium wilt. p. 143-159. In: D.R. Jones (ed.), Diseases of Banana, Abaca and Enset. CABI Publishing, Wallingford, UK.

Schippers, B. and van Eck, W. H. (1981). Formation and survival of chlamydospores in Fusarium. In
Fusarium'. Diseases. Biology and Taxonomy. (P.E. Nelson. T.A. Toussoun. R.J. Cook, eds): 250-260. The Pennysylvania State University Press. University Park and London

Stover, R. H. (1962) a). Studies on Fusarium wilt of bananas. VIII. Differentiation of clones by cultural interaction and volatile substances. Can. Journal of Bot. 40: pp 1467-1471.

Wardlaw, C. W. (1961). Banana Diseases (including plantains and Abaca). Longmans, Green and Co. Ltd. pp 207.

\section{How to cite this article:}

Debashis Rana, Sahar Murmu and Dilip Kumar Misra. 2017. In vitro Studies on Different Isolates of Fusarium oxysporum f sp. cubense Causing Panama Wilt of Banana in Lower Gangetic Plain. Int.J.Curr.Microbiol.App.Sci. 6(12): 1072-1081. doi: https://doi.org/10.20546/ijcmas.2017.612.121 